\title{
Kultúraváltás (vagy -válság) az oktatásban és a kora gyermekkori nevelésben - Előszó a megújulás jegyében
}

\author{
Kolosai Nedda \\ Eötvös Loránd Tudományegyetem Tanitó- és Óvóképzö Kar
}

\section{Lectori salutem!}

Örömmel köszönti kedves Olvasóit a kor kihívásaihoz alkalmazkodva megújuló Gyermeknevelés Tudományos Folyóirat. A megújult szerkesztőség munkájának, valamint az ELTE Egyetemi Könyvtár folyamatos szakmai támogatásának eredményeként a folyóirat 2020 tavaszán csatlakozott a nyílt hozzáférésű folyóiratok nemzetközi rendszeréhez (Open Journal Systems, OJS).

A 2020/2. szám terjedelmét tekintve rendhagyó lett, mivel 24 írásnak adunk lehetőséget az Olvasókkal való párbeszédre. Ezekből tizenkettőt Lénárd András vendégszerkesztő gyüjtött csokorba, a további írásokat a rovatok szempontjai szerint fogadtuk és szerkesztettük. Izgalmas, elgondolkodtató lapszám kerekedett, melyben akadémikus, akadémiai doktor, doktorandusz, tudományos fokozattal rendelkező kutató, valamint a mindennapi pedagógiai gyakorlatát dokumentáló pedagógus írása egyaránt, egyenrangúan olvasható. Határozott koncepciónk a Szerzők személyének, valamint a megjelenő írások tartalmi sokszínüségének megtartása.

\section{Problémafelvetés}

A folyóirat 2020/2. száma arra a kérdésre keresi a lehetséges válaszokat, vajon a jelenlegi társadalmi változások változást vagy válságot idéznek-e elő a bölcsőde, az óvoda, az iskola, a tanulás és tanítás kultúrájában, a kulturális értékteremtésben. Jelenleg hiányoznak a kora gyermekkora vonatkozó, tényekre alapozott, longitudinális kutatások eredményei, pedagógiai gyakorlatok szisztematikus leírásai a témában. Ezt a hiátust kezdjük el kitölteni folyóiratszámunkkal. Fontos tapasztalat, hogy a jelenleg formálódó új iskolakultúrában, óvodakultúrában, bölcsődekultúrában és egyetemkultúrában minden szereplő lázasan keresi a maga helyét, adekvát feladatait.

A kultúra fogalma szemiotikai jellegü, amennyiben a társadalmilag teremtett jelentésstruktúrák összességét értjük alatta, melynek kereteiben 
kiismerjük magunkat abban a világban, melyben cselekedeteink jelekké válnak. A kultúra elsajátítására való képességünk teszi lehetővé emberi közösségeinknek, hogy nagyon változatos kulturális adaptációt használjunk, és gyorsan megváltoztassuk azt, amikor a feltételek megváltoznak, vagy teljesen új adaptációt találjunk. A kultúra megtanulása kritikus tényezője annak a rendszernek, amelyben a biológiai, a pszichikus és a társadalmi aspektusok kölcsönösen felépítik egymást. Ezért van óriási szelekciós előnye annak, ha a gyermek meg tud tanulni hatékonyan alkalmazkodni a közösséghez, a feltételrendszerhez, amelyben él (Super, \& Harness, 2006).

A témába vágó kutatások szerint, a nemzedékek közötti egészséges párbeszédben a gyermek belenő, 'belenevelődik' egy kultúrába és hagyományba. A család, a pedagógusok gyermekkel szemben támasztott fejlődési elvárásai tükrözik a kulturális értékeket. A gyermekek adott térben és időben való felnevelkedésének egyedi élményei és mintázatai egyaránt összefüggést mutatnak a család kulturális vélekedésrendszereivel, valamint az általánosabb társadalmi kulturális hiedelemrendszerekkel (Ligtfoot \& Valsiner, 1992).

Vajon képesek vagyunk-e a kultúraváltásra, a rugalmas alkalmazkodásra olyan helyzetben, amikor az új kultúra ikonográfiai és verbális jelzéseit együtt tanuljuk felnöttek a gyerekekkel, együtt értelmezzük, együtt töltjük meg azokat jelentésekkel.

\section{Új iskolakultúra, új tudás?}

A közoktatás és a felsőoktatás szereplőinek, pedagógusoknak, egyetemi oktatóknak sokszor látszólagos tudathasadásos állapotban kellett és lehetett választaniuk 2020. március közepéig a hagyományos, klasszikusnak nevezett tudáselosztási módok, valamint a megújuló eszközhasználati kihívások között. A közoktatási és az egyetemi intézmények szabály- és követelményrendszere, térbeli elhelyezkedése, megszokott algoritmusai a klasszikus központosított, lineáris gondolkodásra épülő, tankönyvalapú tudáselosztás mechanizmusait támogatták. Folyamatosan találkoztunk szembeállításokkal, melyek egyben burkoltan jónak és rossznak tudását is jelentették: frontális oktatás vagy projektmunka, nagyelőadás vagy kiscsoportos tanulás, egyéni magolás vagy hálózatba szervezett feladatmegoldás, keménykötéses regények olvasása vagy videóklipek nézése, fekete tábla krétával vagy interaktív digitális falitábla használata az oktatásban (Bessenyei, 2009).

Mind a köznevelés intézményei, mind a felsőoktatás szereplői számára sokkolóan érkezett a koronavírus- járvány, villanófény- emléket hagyva maga után. 2020 márciusa és június közepe között nem volt választás, kizárólag távolléti oktatással, így mindenképpen elektronikus tanulási környezetek aktív bevonásával volt teljesíthető a tanulás, a kapcsolattartás.

Az elektronikus tanulási környezetek éles szembeállítása a megszokott tanulási keretrendszerrel, oktatás szervezéssel, a hagyományos falakkal körülvett iskola alternatívájaként felvillantott falak nélküli virtuális iskola absztrakciók. 
Tapasztaltuk, hogy a valóságban minden differenciáltabb, finomabb, ezért lapszámunk a digitális pedagógiával foglalkozó írások mellett több, a kora gyermekkorral, valamint annak felsőoktatás-módszertanával foglalkozó írást is közöl, a különböző perspektívákat egyenrangúan megmutatva.

A kora gyermekkorral foglalkozó kutatások alapvető küldetése, az életkori sajátosságokból, a gyermek valódi szükségleteiből kiindulva átgondolni a tanulási környezetek minőségét. Lényeges megvizsgálni, vajon motivál-e, mire motivál, tanulásra hív-e, ha igen hogyan, fejleszt-e kompetenciákat, változtat-e az életminőségen az adott speciális tanulási környezet.

\section{Kutatások a nevelés és a tanulás kultúrájának megújításához kora gyermekkorban}

Kutatók egyetértenek abban, hogy 2020-ban a legfontosabb kérdés, hogyan lehet a technológia használatát a tanulás hatékonyságának növelése érdekében a megfelelő életkori csoportokban maximalizálni, a differenciált tanulást és tanítást támogatni, a diákok figyelmét és kitartását a feladatmegoldásban növelni, tanulási motivációjukat fenntartani (Molnár, Turcsányi-Szabó \& Kárpáti, 2020).

Csépe Valéria akadémikus és Török Ágoston írásában olvashatjuk, hogy a mobiltechnológiák (okostelefon, táblagép stb.) oktatási célú alkalmazását elemző tanulmányok többsége arra hívja fel a figyelmet, hogy megfelelő oktatási környezetben, kifejezetten hasznos ezeknek a technológiáknak az alkalmazása (Csépe \& Török, 2020). A mobil technológiák a kisgyermek ágencia motívumára hatnak, ezért azok többcélú alkalmazása, beépítése az oktatásba a motivált tanulás, valamint az általános és a tanulási területre specifikus kognitív képességek fejlesztésének egyik lehetséges útja (Csépe \& Török, 2020). Koscsóné Kolkopf Judit és Kiss Heléna bölcsődében dolgozva mindennap szembesülnek a hároméves kor alatti gyermekek, családok, bölcsődei kisgyermeknevelők digitális eszközhasználati szokásaival. Digitális Honfoglalás / Digital Skills címmel olyan egyedülálló kutatásba kezdtek, melyben szisztematikusan keresnek válaszokat a kora gyermekkori eszközhasználat által felvetett kérdésekre, az eszközhasználat mögötti attitűdökre is fókuszálva. Kutatásukból kiderül, már a bölcsődéskorú gyermekek nagy része használ okoseszközt. A szülők saját elmondásuk szerint maguk nem járatosak az eszközhasználatban, azt leggyakrabban figyelemelterelésre, a gyermek megnyugtatására használják. A kérdőívek elemzéséből kiderül, a szülők saját megéléseik szerint gyermeküket eszközhasználat közben felügyelik, miközben olyan helyzetekben kapják meg a kisgyermekek az eszközöket, amikor a szülő figyelme folyamatosan másra irányul. A szerzők megfogalmazásában ebben a világban a felnőttek nem okosak, a gyermekek nincsenek biztonságban (Koscsóné Kolkopf \& Kiss, 2020).

A kora gyermekkori intézményekben történő ellátás, az úgynevezett intézményes nevelés mellett és ellen több érvet is fel lehet hozni (Lukács, 2017). Kapcsolódva az előzőekben említett kutatáshoz, az egyik érv a bölcsődei ellátás mellett, hogy azok a gyermekek, akik jártak bölcsődébe, jobban 
fejlődnek, a későbbiekben jobban teljesítenek. Ugyancsak a bölcsődék szakmaiságát emeli ki az az érv, hogy egy jól működő intézményi ellátórendszer képes kompenzálni a családból hozott társadalmi hátrányokat, így hozzájárul a társadalmi egyenlőtlenségek csökkentéséhez. Kapitány Balázs tanulmányában olyan, a gyermeket vállalók bölcsődéztetési terveire vonatkozó eredményeket mutat meg, melyek a Kohorsz18 - Magyar születési kohorszvizsgálat várandós mintájából származnak. A 2018-ban zajló kutatás 8409 fő 7. hónapban lévő magzatról, a várandós anyákról, valamint társadalmi-gazdasági életkörülményeikről gyüjtött részletes adatokat. A tanulmány szerényen leírónak nevezi a megmutatott eredményeket, ugyanakkor a Szerző komolyan elemzi, összefüggéseiben vizsgálja a kutatás adatait (Kapitány, 2020).

Miklósi Ádám, az MTA doktora, kutatócsoportjával azt vizsgálja, hogyan hat a mobileszköz-használat az óvodások figyelmére és társas-kognitív készségeire. Jelen folyóiratszámban bemutatott kutatás eredményei (is) alátámasztják, hogy a most felnövő generációk kognitív és társas készségeit jelentősen befolyásolja a digitális eszközök hosszabb vagy egészen rövid távú használata. A kutatásokból származó tapasztalatokat a gyerekeknek szóló digitális felületek tervezésekor egyaránt felhasználja a kutatócsoport. Az Alfa Generáció Labor egy ilyen, kezdőalkalmazásként is funkcionáló, az egész eszköz működését átszövő felületen dolgozik, alkalmazkodva a gyerekek megváltozott kognitív müködéséhez, egyúttal biztonságos közeget teremtve számukra a digitális térben. Az applikáció célja, hogy a játékos készségfejlesztésen túl megfelelően korlátozza a digitális aktivitást (időkorlát felállítása), valamint az interaktív ágens és a társak (szülők, testvérek) bevonásával szociális ingerek nyújtása a gyerekek számára (Konok et al., 2020).

Az IKT-eszközök használata óvodáskorban - Egy kérdöív nyílt tételeinek kódolása EKOD-makrócsomaggal címü tanulmány azoknak a kutatóknak ad példákkal alátámasztott, azonnali segítséget, akik kvalitatív eszközökkel is kutatják a területet (B. Németh et al., 2020).

Fehér Péter nagyon aktuális írásában áttekinti a digitális oktatás jelenlegi helyzetét, bemutatja a téma nemzetközi gyakorlatának aktuális kérdéseit, az oktatásinformatika hangsúlyának változásait, a fejlődés trendjeit, néhány lehetséges irányát. Kutatása alapján megállapítja, hogy a közeli jövőben leginkább érdeklődésre számot tartó témakörök az oktatásinformatikában az oktatási robotika alkalmazása, annak továbbfejlesztése; a kiterjesztett valóságalkalmazások; a digitális történetmesélés; a kódolás tanulása játékos és valódi, kézzelfogható eszközök felhasználásával; a számítógépes gondolkodás gyakorlatba való átültetésének kérdései, valamint az SNI diákok IKT- és más kompetenciáinak fejlesztési lehetőségei a korszerü digitális technológiák bevonásával (Fehér, 2020). Aknai Dóra Orsolya írásában arra az izgalmas kérdésre keresi a választ, vajon pontosan milyen szerepet tölthet be egy robot a tanítási órán. Az írás hiteles választ ad a kérdésre, hiszen gyakorló gyógypedagógusként a mindennapi pedagógiai gyakorlatban sajátos nevelési igényü gyermekek oktatásában alkalmazza rendszeresen a padlórobotokat (Aknai, 2020). 


\section{Kutatások az oktatás kultúrájának megújításához a felsőoktatásban}

A pedagógusképzés és a közoktatás szoros kapcsolódása miatt, egyetemi hallgatók digitális pedagógiai kompetenciáinak fejlesztéséhez szükség van a képzésük során megjelenő explicit, a digitális eszközhasználat elsajátíttatására fókuszáló kurzusokra, valamint implicit, az oktatási folyamatba ágyazott online fejlesztési lehetőségek elsajátítására fókuszáló kurzusokra egyaránt (Dringó-Horváth \& Gonda, 2018).

A témában megjelenő friss nemzetközi és hazai kutatások eredményei szerint egyetemi oktatók és közoktatásban dolgozó pedagógusok alapvetően szemléltetésre, ismeretátadásra használják a digitális eszközöket. Jelenleg mindez nem tekinthető adaptívnak, mára alapkövetelménynek számít a 21. századi kompetenciák fejlesztésére, a tanulók aktivitására, önállóságára építő tudatos, változatos digitális pedagógiai módszertan alkalmazása (Tóth-Mózer \& Misley, 2019). Az oktatók ugyanakkor úgy vélik, egy magasabb szintü digitális pedagógiai kultúra kialakulásához szükséges, hogy intézményeik megfelelő infrastruktúrát, elérhető továbbképzéseket biztosítsanak számukra, egyben, hogy olyan szabályozás irányítsa munkájukat, amely lehetővé teszi és ösztönzi a digitális pedagógiai megoldásokat (Horváth et al., 2020). További kutatások is kiemelik, hogy az eredményes és hatékony digitális fejlesztés egyik kulcsa az oktatók módszertani fejlődésének segítése (Serfőző et al., 2020).

A közoktatás és a pedagógusképzés szoros kapcsolódását mutatja az a tény is, hogy a pedagógusok mindennapi pedagógiai gyakorlatában alkalmazott módszertani megoldásaiban a szaktudományos ismeretek, illetve a pedagógusképzésben tanultak ellenében is sokszor a saját, tanulóként megélt, az oktatási gyakorlatban tapasztalt momentumok hatnak. Ezzel párhuzamosan kutatások mutatják, hogy az informatika tanításában olyan téveszmék vannak jelen, melyek sok tanulót érintve terjednek tovább. Mindezen okok miatt Lénárd András tanulmányában a fekete pedagógia jelenségköréből és a pedagógus kutatások eredményeiből kiindulva vizsgálja, hogy tanító szakos pedagógushallgatók milyen tapasztalatokkal, rendelkeznek, a közoktatás keretein belül megvalósuló informatika oktatásról. A kutatás elsősorban az informatikatanítás területén szerzett olyan közvetlen tapasztalatokra fókuszál, melyek hatással lehetnek pedagógusjelöltek későbbi tanítási tevékenységeire. A vizsgálat tapasztalatai jól hasznosíthatóak voltak az informatika tantárgy tartalmi és módszertani megújítása során is az újonnan létrehozott digitális kultúra tantárgy tantervi tartalmainak kialakításánál. A tanulmányban olvasható eredmények hozzájárultak ahhoz, hogy az Nemzeti alaptanterv részeként, az információs társadalom elvárásainak és a tanulók érdeklődésének, életkori sajátosságainak megfelelő, új tantárgy születhessen (Lénárd, 2020).

Az Európai Bizottság a DigComp digitális keret megalkotásával kompetenciaterületekben fogalmazta meg azokat a részkompetenciákat, amivel az egyén versenyképességét növelni tudja a munkaerőpiacon. Turzó-Sovák Nikolett írásában bemutatja ezeket a kompetenciaterületeket. 
Mivel a megadott részkompetenciák irányadóak a felsőoktatásban folyó pedagógusképzés számára, az ELTE Tanító- és Óvóképző Kar, Digitális Pedagógiai Tanszéke, a tanszék által szervezett kurzusokon a hallgatókat az európai szabványkeretnek megfelelően készíti fel pedagógiai munkájukra (Turzó-Sovák, 2020).

Borbáth Katalin a pszichológus szempontjából közelít a felsőoktatás, a pedagógusképzés aktuális kérdéseihez, írásában pedagógusok mentális egészségével, ennek felsőoktatás-pedagógiai vonatkozásával is foglalkozik (Borbáth, 2020).

\section{Szakmódszertani gyakorlatok bemutatása a mindennapi pedagógiai munka hatékonyságának növelésére}

A hagyományos pedagógiai módszerek mellett a múzeum falai között is alkalmazhatóak új pedagógiai módszerek, melyek hatékonyabbá teszik a gyermeki tanulást. Schlichter-Takács Anett és Csimáné Pozsegovics Beáta kutatásokra alapozva kidolgozott egy múzeumpedagógiai foglalkozást iskolások számára. A tanulmány hozzájárulhat mind a múzeumpedagógiai munka módszertani megújulásához, mind gyakorló pedagógusok múzeum iránti lelkesedésének felkeltéséhez (Schlichter-Takács \& Csimáné Pozsegovics, 2020).

Csirkés Zsolt és Csongor Nóra Erika empirikus kutatási eredményekkel alátámasztva, az óvodás- és kisiskoláskori egyensúlyozó-képesség fejlesztésével, a vesztibuláris ingerlés fontosságára hívják fel pedagógusok figyelmét. A kutatás eredményei szerint már három hónapos szenzomotoros torna hatására a vizsgálati csoportba tartozó gyermekek egyensúlyértékei javultak (Csirkés \& Csongor, 2020). Az egyensúlyrendszer nem megfelelő fejlődése a magatartásszabályozás és a viselkedéskontroll zavaraival járhat. Ezért érdemes a szerzők által használt egyszerü gyakorlatokat, valamint a nagymozgások támogatásának szemléletét népszerűsíteni.

Maróti Emese munkatársaival azt a kérdést járja körül, vajon hogyan egyeztethető össze az egyik legszemélyesebb és leghumánabb tantárgy, az ének-zene, a digitális technológiával? A tanulmány eléri azt a célját, hogy a digitális eszközök használatát a pedagógusok akadály helyett lehetőségként lássák. A Szerzők által szisztematikusan, életkoronkénti bontásban összeállított ajánlott gyüjtemény pedig kezdeti segítséget ad az ének-zene oktatás digitális módszertani hiányainak pótlásához (Maróti et al., 2020).

Szűcs Dóra könyvismertetésében részletesen megmutatja az Okos Doboz Módszertani kézikönyv felépítését, tartalmait. A kézikönyv többek között olyan hiánypótló kérdésekkel foglalkozik, mint a gyerekeket is érintő információszürés, valamint a generációs tipizálás sematikusságának lehetséges negatív hatása a pedagógiai munkában zajló differenciálásra.

Márkus Éva recenziójában felhívja a figyelmet arra a lényeges aspektusra, hogy a csecsemőgondozás és kisgyermeknevelés szakembereinek naprakész szakirodalmi tájékozottsággal szükséges rendelkezniük. Az általa részletesen bemutatott szakirodalomban megjelenik a kiválasztási autonómia fogalma, mely terminus egyben a megváltozott perspektívákra is ráirányítja a szakemberek figyelmét. 
A pedagógusok folyamatos szakmai fejlődése és tanulása (Rapos et al., 2020), olyan új fogalom a hazai szakirodalomban, melyben nem csak a tanulás eredményének, azaz a szakmai tudásnak, hanem az ahhoz vezető folyamatnak egyaránt lényeges szerep jut. A kora gyermekkori pedagógiával - a mindennapi pedagógiai gyakorlatban, valamint az akadémiai kutatásban - foglalkozók számára, ehhez az élvezetes tanulási folyamathoz, az önfejlesztéshez kíván hozzájárulni a lapszám.

\section{Irodalom}

Aknai, D. O. (2020). A robotika szerepe az SNI tanulók fejlesztésében. Gyermeknevelés Tudományos Folyóirat, 8(2), 146-163, https://doi.org/10.31074/ gyntf.2020.2.146.163

Bessenyei, I. (2009). A net-generáció új tudása. Élet és Irodalom, 53(6), https://www. es.hu/cikk/2009-02-04/bessenyei-istvan/a-net-generacio-uj-tudasa.html

Bers, M.U. (2018). Coding as a Playground: Programming and Computational Thinking in the Early Childhood Classroom. Routledge Press.

Borbáth, K. (2020). Gondolatok a pedagógusok mentális jóllétének aspektusairól és azok hatásairól. Gyermeknevelés Tudományos Folyóirat, 8(2), 299-317, https:// doi.org/10.31074/gyntf.2020.2.299.317

B. Németh, M., Juhász, F., Hódi, Á. \& Tóth, E. (2020). IKT-eszközök használata óvodáskorban - Egy kérdőív nyílt tételeinek kódolása EKOD-makrócsomaggal Gyermeknevelés Tudományos Folyóirat, 8(2), 32-54, https://doi.org/10.31074/gyntf.2020.2.32.54

Csépe, V. \& Török, Á. (2020). Az okoseszközök használata kognitív idegtudományi nézőpontból. Gyermeknevelés Tudományos Folyóirat, 8(2), 133-145, https://doi. org/10.31074/gyntf.2020.2.133.145

Csirkés, Zs. \& Csongor, N. E. (2020). Három hónapos szenzomotoros torna hatása óvodások és kisiskolások egyensúlyozó képességére. Gyermeknevelés Tudományos Folyóirat, 8(2), 260-298, https://doi.org/10.31074/gyntf.2020.2.260.298

Dringó-Horváth, I. \& Gonda, Zs. (2018). Tanárjelöltek IKT-kompetenciájának mérése. Képzés és Gyakorlat Folyóirat, 16(2), 21-47. https://doi.org/10.17165/ TP.2018.2.2

Fehér, P. (2020). „Húsz év múlva” - A digitális oktatás helyzete, eszközei, trendjei világszerte. Gyermeknevelés Tudományos Folyóirat, 8(2), 348-370, https://doi. org/10.31074/gyntf.2020.2.348.370

Horváth, L., Misley, H., Hülber, L., Papp-Danka, A., M. Pintér, T. \& Dringó-Horváth, I. (2020). Tanárképzők digitális kompetenciájának mérése - a DigCompEdu adaptálása a hazai felsőoktatási környezetre. Neveléstudomány, 7(1), 5-25. https://doi.org/10.21549/NTNY.29.2020.2.1

Konok, V., Peres, K., Ferdinandy, B., Jurányi, Zs., Bunford, N., Ujfalussy, D. J., Réti, Zs., Kampis, Gy. \& Miklósi, Á. (2020). Hogyan hat a mobileszköz-használat az óvodások 
figyelmére és társas-kognitív készségeire? Gyermeknevelés Tudományos Folyóirat, 8(2), 13-31, https://doi.org/10.31074/gyntf.2020.2.13.31

Koscsóné Kolkopf J. \& Kiss, H. (2020). „Digitális Honfoglalás” avagy 0-3 évesek a digitális világban. Gyermeknevelés Tudományos Folyóirat, 8(2), 202-218, https://doi. org/10.31074/gyntf.2020.2.202.218

Lénárd, A. (2020). Fekete pedagógia, avagy hallgatói tapasztalatok az informatika tantárgy oktatásáról. Gyermeknevelés Tudományos Folyóirat, 8(2), 184-201. https://doi.org/10.31074/gyntf.2020.2.184.201

Lightfoot, C., \& Valsiner, J. (1992). Parental belief systems under the influence: Social guidance of the construction of personal cultures. In Sigel, I. E., McGillicuddyDeLisi, A.V. \& Goodnow, J.J. (Eds.), Parental belief systems: The psychological consequences for children (pp. 393-414). Lawrence Erlbaum Associates.

Lukács, P. (2017). Egy megvalósult és egy tervezett reformról. Educatio, 26(4), 557-566.

Márkus, É. (2020). Bölcsődés gyerekek odafigyelő segítése - Könyvismertetés. Gyermeknevelés Tudományos Folyóirat, 8(2), 344-347.

Maróti, E. (2020). A digitális környezet, mint lehetőség a zenei nevelésben. Gyermeknevelés Tudományos Folyóirat, 8(2), 318-331, https://doi.org/10.31074/gyntf.2020.2.318.331

Molnár Gy., Turcsányi-Szabó, M. \& Kárpáti, A. (2020). Digitális forradalom az oktatásban - Perspektívák és dilemmák. Magyar Tudomány, 181(1) 59-67.

Rapos, N., Bükki, E., Gazdag, E., Nagy, K. \& Tókos, K. (2020). A pedagógusok folyamatos szakmai fejlődése és tanulása. Fogalmi változások. Neveléstudomány, 7(1), 28-45. https://doi.org/10.21549/NTNY.28.2020.1.2

Super, C. M. \& Harness, S. (2006). A gyermeki fejlődés kulturális szerveződése. In Fülöp, M. \& Nguyen Luu, L.A. (2006). Kultúra és pszichológia (pp. 335-365). Osiris Kiadó.

Schlichter-Takács, A. \& Csimáné Pozsegovics, B. (2020). Múzeumpedagógia újragondolva: A kaposvári Rippl-Rónai Múzeum múzeumpedagógiai foglalkozásainak vizsgálata, módszertani megújítása. Gyermeknevelés Tudományos Folyóirat, 8(2), 214-241, https://doi.org/10.31074/gyntf.2020.2.214.241

Serfőző, M., Golyán, Sz., F. Lassú, Zs., Svraka, B., \& Aggné Pirka, V. (2020). Digitalizáció és online tanulás a pedagógusképzésben - Hallgatói visszajelzések a távolléti oktatásról. (kutatás közben) Civil Szemle, 17

Szűcs, D. (2020). Az Okos Doboz Módszertani kézikönyv bemutatása. Gyermeknevelés Tudományos Folyóirat, 8(2), 338-343.

Tóth-Mózer, Sz. \& Misley, H. (2019). IKT-eszközök integrálása az oktatásba. Módszertani útmutató pedagógusoknak. ELTE PPK.

Turzó-Sovák, N. (2020). Pedagógushallgatók digitális kompetenciáinak fejlesztési lehetőségei. Gyermeknevelés Tudományos Folyóirat, 8(2), 164-173, https://doi. org/10.31074/gyntf.2020.2.164.173

Kolosai Nedda: https://orcid.org/0000-0001-7932-4443 